\title{
Effects of stage of lactation and dietary forage level on body composition of Alpine dairy goats
}

\author{
A. T. Ngwa, ${ }^{*}$ L. J. Dawson, ${ }^{*} \dagger$ R. Puchala, ${ }^{*}$ G. Detweiler, ${ }^{*}$ R. C. Merkel, ${ }^{*}$ Z. Wang, ${ }^{*}$ K. Tesfai, ${ }^{*}$ T. Sahlu, ${ }^{*}$ \\ C. L. Ferrell, $\ddagger$ and A. L. Goetsch*1 \\ *American Institute for Goat Research, Langston University, Langston, OK 73050 \\ †College of Veterinary Medicine, Oklahoma State University, Stillwater 74078 \\ fUSDA, ARS, US Meat Animal Research Center, Clay Center, NE 68933
}

\section{ABSTRACT}

Multiparous Alpine does (42) were used to determine how stage of lactation and dietary forage level affect body composition. The feeding and body composition portion of the study had a $2 \times 3$ factorial arrangement of treatments. Eighteen does were fed a $40 \%$ forage diet $(40 \mathrm{~F})$ and 18 received a diet with $60 \%$ forage $(60 \mathrm{~F})$ for approximately 2, 4, or 6 mo of lactation ( $59 \pm 1.3$, $116 \pm 1.0$, and $184 \pm 1.4 \mathrm{~d}$, respectively), followed by determination of body composition (6 does per diet at each time of slaughter). Does were assigned sequentially to treatments as kidding occurred. The $60 \mathrm{~F}$ diet had $20 \%$ more dehydrated alfalfa pellets than the $40 \mathrm{~F}$ diet, with higher levels of corn and soybean meal and inclusion of supplemental fat in the $40 \mathrm{~F}$ diet. Initial body composition measures were made with 6 other does a few days after kidding $(0 \mathrm{mo} ; 4 \pm 0.6 \mathrm{~d})$. Before parturition, does were fed a $50 \%$ concentrate diet free choice. Intake of dry matter was greater for $60 \mathrm{~F}$ than for $40 \mathrm{~F}$, average daily gain tended to be affected by an interaction between diet and month $(0,24,121,-61$, 46 , and $73 \mathrm{~g}$ ), and $4 \%$ fat-corrected milk was less in mo 5 to 6 than earlier. Internal fat mass was greatest among times at $6 \mathrm{mo}$ and greater for $40 \mathrm{~F}$ than for $60 \mathrm{~F}$. Mass of the gastrointestinal tract was less for $40 \mathrm{~F}$ than for $60 \mathrm{~F}$ and decreased with increasing time in lactation. Concentrations of fat in the carcass $(13.8,13.1,16.5$, $11.2,11.5$, and $14.4 \%$ ), noncarcass tissues (18.6, 24.2, $33.3,14.3,16.5$, and $24.5 \%$ ), and empty body (16.5, $18.7,25.2,12.9,14.1$, and $19.5 \%$ for $40 \mathrm{~F}$ at $2 \mathrm{mo}, 40 \mathrm{~F}$ at $4 \mathrm{mo}, 40 \mathrm{~F}$ at $6 \mathrm{mo}, 60 \mathrm{~F}$ at $2 \mathrm{mo}, 60 \mathrm{~F}$ at $4 \mathrm{mo}$, and $60 \mathrm{~F}$ at $6 \mathrm{mo}$, respectively) were affected by stage of lactation and diet. Based on daily change in tissue mass and energy, energy concentration in tissue mobilized or accreted was 16,20 , and $32 \mathrm{MJ} / \mathrm{kg}$ in 1 to 2,3 to 4 , and 5 to 6 mo of lactation, respectively. In conclusion,

Received January 26, 2009.

Accepted March 25, 2009.

${ }^{1}$ Corresponding author: goetsch@luresext.edu based on tissue mass, more energy was expended by the gastrointestinal tract with $60 \mathrm{~F}$ than with $40 \mathrm{~F}$. Considerable internal fat appeared to be mobilized in early lactation, particularly with the diet moderate to high in forage, with more rapid and a greater magnitude of repletion by does consuming the diet lower in forage. The concentration of energy in tissue mobilized or accreted varied with stage of lactation, being considerably greater at 5 to 6 mo of lactation than earlier.

Key words: dairy goat, lactation, body composition

\section{INTRODUCTION}

A complete understanding of the composition of tissue being accreted or mobilized is necessary to determine dietary energy needs. For lactating dairy goats, factors that may influence the composition of tissue being lost or gained are potential for milk production, diet quality, stage of lactation, and interactions among these factors. Sahlu et al. (2004) and NRC (2007) used the constant concentration of energy in tissue both being gained and being lost of AFRC (1998; $23.9 \mathrm{MJ} / \mathrm{kg})$. Conversely, Ngwa et al. (2007a) noted that the energy concentration in tissue mobilized by yearling meat goats with initially high BW and BCS was considerably lower. Furthermore, the energy concentration in tissue being gained by wethers that previously had low BW and BCS while on a high plane of nutrition was greater than that in mobilized tissue and differed markedly between 2 sequential 12-wk feeding periods.

In addition to the desirability of knowing the chemical composition of tissue lost or gained on a whole or empty body basis, it is also of interest to know how factors such as diet and stage of lactation influence the mass of specific organs and tissues, particularly ones such as the gastrointestinal tract and liver, which are metabolically expensive. Therefore, the objectives of this experiment were to determine how stage of lactation and dietary forage level would affect the mass of organs and tissues and the chemical composition of tissue of Alpine does. 
Table 1. Ingredient and chemical composition of diets consumed by lactating Alpine does (\% of DM)

\begin{tabular}{lrr}
\hline Item & $40 \mathrm{~F}^{1}$ & $60 \mathrm{~F}^{2}$ \\
\hline Ingredient & & \\
Bermudagrass hay & 20.00 & 20.00 \\
Dehydrated alfalfa pellets & 20.00 & 40.00 \\
Ground corn & 21.95 & 12.80 \\
Soybean meal & 10.00 & 0.00 \\
Wheat middlings & 17.00 & 21.00 \\
Molasses $_{\text {Fat }}^{3}$ & 5.00 & 5.00 \\
Limestone $_{\text {Vitamin premix }}^{4}$ & 3.00 & 0.00 \\
Trace mineralized salt & 5.94 & 0.15 \\
Magnesium oxide & 0.50 & 0.50 \\
Sodium bicarbonate & 0.50 & 0.50 \\
Chemical composition & 0.11 & 0.05 \\
OM & 1.00 & 0.00 \\
CP & & \\
NDF & 89.5 & 90.7 \\
\hline
\end{tabular}

${ }^{1} 40 \mathrm{~F}=40 \%$ forage.

${ }^{2} 60 \mathrm{~F}=60 \%$ forage.

${ }^{3}$ Megalac (Church and Dwight Inc., Lakewood, NJ).

${ }^{4} 96$ to $99 \% \mathrm{NaCl}$ and at least $0.24 \% \mathrm{Mn}, 0.24 \% \mathrm{Fe}, 0.05 \% \mathrm{Mg}, 0.032 \%$ $\mathrm{Cu}, 0.011 \% \mathrm{Co}, 0.004 \% \mathrm{I}$, and $0.032 \% \mathrm{Zn}$.

${ }^{5} 8,800 \mathrm{IU} / \mathrm{kg}$ of vitamin $\mathrm{A}, 1,760 \mathrm{IU} / \mathrm{kg}$ of vitamin $\mathrm{D}_{3}$, and $1.1 \mathrm{IU} / \mathrm{kg}$ of vitamin $\mathrm{E}$.

\section{MATERIALS AND METHODS}

\section{Body Composition}

The protocol for this experiment and the experiment for determination of digestibility was approved by the Langston University Animal Care Committee. Fortytwo multiparous lactating Alpine does were used in the body composition experiment. Six were used for initial or 0-mo slaughter measures early after parturition $($ mean $=4 \mathrm{~d}$, SEM $=0.6 \mathrm{~d}$, minimum $=2 \mathrm{~d}$, and maximum $=6 \mathrm{~d}$ ). The other 36 does were assigned sequentially to 1 of 6 treatments as kidding occurred. This was conducted so that DIM would be similar between dietary treatments at the 3 times of slaughter and for a constant interval between slaughters. Three of the treatments entailed ad libitum consumption of a $40 \%$ forage, $60 \%$ concentrate diet (abbreviated as 40F), and the other 3 treatments involved ad libitum intake of a $60 \%$ forage, $40 \%$ concentrate diet (abbreviated as $\mathbf{6 0 F}$; Table 1). The intent was to have diets high in nutritive value but that differed in ingredient composition conceivably to elicit differences in tissue mobilization, accretion, or both. The $60 \mathrm{~F}$ diet had $20 \%$ more dehydrated alfalfa pellets than the $40 \mathrm{~F}$ diet, with higher levels of corn and soybean meal and inclusion of supplemental fat in the $40 \mathrm{~F}$ diet. Fat was included in the $40 \mathrm{~F}$ diet to increase the difference in ME concentration above that resulting from different dietary forage levels. Six does from each dietary treatment were used for slaughter measures at $2($ mean $=59 \mathrm{~d}, \mathrm{SEM}=1.3$ $\mathrm{d}$, minimum $=53 \mathrm{~d}$, and maximum $=65 \mathrm{~d}), 4($ mean $=$ $116 \mathrm{~d}, \mathrm{SEM}=1.0 \mathrm{~d}$, minimum $=111 \mathrm{~d}$, and maximum $=124 \mathrm{~d})$, and 6 mo of lactation $($ mean $=184 \mathrm{~d}, \mathrm{SEM}=$ $1.4 \mathrm{~d}$, minimum $=174 \mathrm{~d}$, and maximum $=189 \mathrm{~d}$ ).

Does were treated for clostridial organisms and internal parasites (Valbazen, SmithKline Beecham Animal Health, West Chester, PA) before kidding. Does kidded in maternity pens, and kids were removed at birth. Does remained in maternity pens for $24 \mathrm{~h}$ and then were transferred to a facility with pens fitted with Calan feeding gates (American Calan Inc., Northwood, $\mathrm{NH}$ ). Does slaughtered for 0-mo measures continued to receive a $50 \%$ concentrate diet given during late pregnancy. All does were accustomed to use of the Calan feeding gates.

Does consuming $40 \mathrm{~F}$ were placed in 3 pens ( 6 per pen) and those consuming $60 \mathrm{~F}$ were in another 3 pens. Diets were fed at approximately $120 \%$ of consumption on the preceding few days. Milk production was determined each day at 0400 and $1600 \mathrm{~h}$, and milk samples were collected at both times $1 \mathrm{~d}$ weekly. Samples were stored in vials with potassium bromide as a preservative until analysis for fat, protein, lactose, TS, SNF, and SCC at the certified DHIA Laboratory for Goats at Langston University. Milk composition was determined with a MilkoScan 400 analyzer (Foss Electric, Hillerød, Denmark) and SCC was determined with a Fossomatic 5000 analyzer. Both instruments were calibrated monthly. Log-transformed SCC was statistically analyzed. At 2, 4, and 6 mo of lactation, 2 does were randomly selected from each pen for slaughter measures, which occurred over a 2-d period. Diet samples were collected daily for formation of weekly composite samples. Diet samples were analyzed for DM, ash, CP (AOAC, 1990), and NDF (filter bag technique; Ankom Technology Corp., Fairport, NY).

On the morning before slaughter, all does were weighed full or unshrunk and BCS was determined by a panel of 3 individuals, with 0.25 -increments, as described by Ngwa et al. (2007b). After a 24-h period without feed or water, does were slaughtered via stunning with a captive bolt pistol and exsanguination. Blood was collected and weighed. The esophagus was ligated and the head, hooves, and skin were removed and weighed. The rectum was ligated and the entire alimentary tract was removed and weighed before separation into components (esophagus, reticulorumen, omasum, abomasum, small intestine, large intestine, and cecum) by ligation and cutting. Components were weighed with digesta and then without after washing and blotting with paper towels. Noncarcass or internal fat was the sum of visceral and perirenal depots. The carcass and noncarcass organs and tissues were 
expressed in grams and relative to empty BW (EBW), which was the sum of these components minus mass of digesta of the gastrointestinal tract (GIT).

Pools of weighed noncarcass components (blood, head, hide, organs, and fat) and the carcass were ground (Model 801 Autogrinder; Austio Company, Astoria, OR) separately 3 times sequentially through each of 3 plates with different apertures (i.e., 10, 5, and 2 $\mathrm{mm})$. After the final grind, the sample was hand-mixed and duplicate $250 \mathrm{~g}$ aliquots were collected and stored at $-20^{\circ} \mathrm{C}$. Carcass and noncarcass pool samples were analyzed for DM by lyophilization (Model CRVP-195P Dura Stop, FTS Systems, Stone Ridge, NY). After drying, samples were dipped in liquid nitrogen for approximately $1 \mathrm{~min}$ and then reground in a blender (Model CB16, Waring Commercial, Torrington, CT) and analyzed for CP, ash (AOAC, 1990), and fat. Fat was determined with the Ankom ${ }^{\mathrm{XT15}}$ Extraction System (Ankom Technology Corp., Macedon, NY). Energy concentrations of 39.3 and $23.1 \mathrm{MJ} / \mathrm{kg}$ were assumed for fat and protein, respectively (ARC, 1980). Composition of accreted tissue was based on full BW of does at the time of slaughter and the composition of does of the same dietary treatment on a full BW basis at the preceding time of slaughter. To estimate tissue concentrations of ash, protein, fat, and water, the sum of mass of each constituent was estimated for the carcass and noncarcass tissue pools, rather than using fresh mass values for the carcass and noncarcass organs and tissues determined on the day of slaughter.

Data were analyzed with a $2 \times 3$ factorial treatment arrangement using the GLM procedure (SAS Institute Inc., Cary, NC), with a model consisting of diet, slaughter time $(2,4$, and $6 \mathrm{mo})$, and the diet $\times$ slaughter time interaction. Interaction means are presented in tables in all cases. Main effect means for time were included when the effect was significant $(P<0.05)$ and the diet $\times$ treatment interaction was nonsignificant $(P>0.05)$. The $P$-value for the main effect of diet is included in tables as well. Milk production and composition data were averaged for does slaughtered at 2,4 , and 6 mo over mo 1 to 2,3 to 4 , and 5 to 6 , respectively. Means were separated by least significant difference. For 0-mo slaughter measures, means and SEM were estimated.

\section{Digestibility}

Twelve additional does were likewise sequentially assigned after kidding to the $40 \mathrm{~F}$ and $60 \mathrm{~F}$ diets. Two does from each treatment were housed in each of the Calan feeding gate pens with animals for slaughter measures of the same diet. In the middle of mo 1 to 2 and 3 to 4 , does were moved to another facility and placed in metabolism crates for $10 \mathrm{~d}$. The first $5 \mathrm{~d}$ was for adaptation, and total feces excreted were collected over the next $5 \mathrm{~d}$. Feed and feed refusals were collected each day to form composite samples. A $10 \%$ aliquot of feces excreted was collected each day to form a composite sample and later dried by lyophilization. Samples were ground in a Wiley mill to pass a 1-mm screen and analyzed for DM, ash, CP (AOAC, 1990), and NDF (filter bag technique; Ankom Technology Corp.).

There were 6 observations per diet at each of the 2 periods of determination. Data were analyzed using the MIXED procedure (SAS Institute Inc., Cary, NC). The model consisted of the fixed effects of diet, the repeated measure of time, and the treatment $\times$ time interaction as well as the random effect of animal. Means were separated by least significant difference.

\section{RESULTS}

\section{Diet Composition and Digestibility}

Composition was similar among samples within dietary treatments collected during the experiment. The NDF concentration was greater for $60 \mathrm{~F}$ than for 40F (Table 1). The dietary CP concentration was not greatly different between diets.

Dry matter intake in the digestibility trial tended $(P$ $<0.09$ ) to be greater for $60 \mathrm{~F}$ than for $40 \mathrm{~F}$ (Table 2 ). A similar trend was noted for intake of OM $(P<0.07)$. There were interactions between diet and time in DM and $\mathrm{OM}$ digestibilities $(P<0.05)$. Digestibilities of DM and $\mathrm{OM}$ were similar between diets in mo 1 to 2 but were greater for $40 \mathrm{~F}$ than for $60 \mathrm{~F}(P<0.05)$ in mo 3 to 4 . Digestible DM and OM intakes were not affected by diet or time. Intake of $\mathrm{CP}$ was similar between diets and periods $(P>0.10)$. Digestibility of $\mathrm{CP}$ was similar between diets and tended $(P<0.09)$ to be greater in mo 1 to 2 than in mo 3 to 4 . As anticipated, NDF intake was greater for $60 \mathrm{~F}$ than for $40 \mathrm{~F}(P<0.05)$. In mo 3 to 4, NDF digestibility was similar between diets $(P>0.10)$ but was greater for $60 \mathrm{~F}$ than for $40 \mathrm{~F}(P<$ $0.05)$ in mo 1 to 2 .

\section{BW, BCS, and Milk Production and Composition}

Initial average BCS was $2.4(\mathrm{SEM}=0.07)$. There were tendencies $(P<0.07)$ for interactions between time and diet in ADG $(P<0.07)$ and change in BCS $(P<0.08$; Table 3$)$. Nonetheless, averaged over diet ADG ranked $(P<0.05)$ mo 1 to $2<3$ to $4<5$ to 6 , with BW gain in late lactation equivalent to loss in early lactation. Change in BCS was less in mo 1 to 2 compared with later times $(P<0.05)$, being negative in 
Table 2. Effects of dietary concentrate level on intake and digestibility by Alpine does determined at 1 to 2 and 3 to 4 mo of lactation

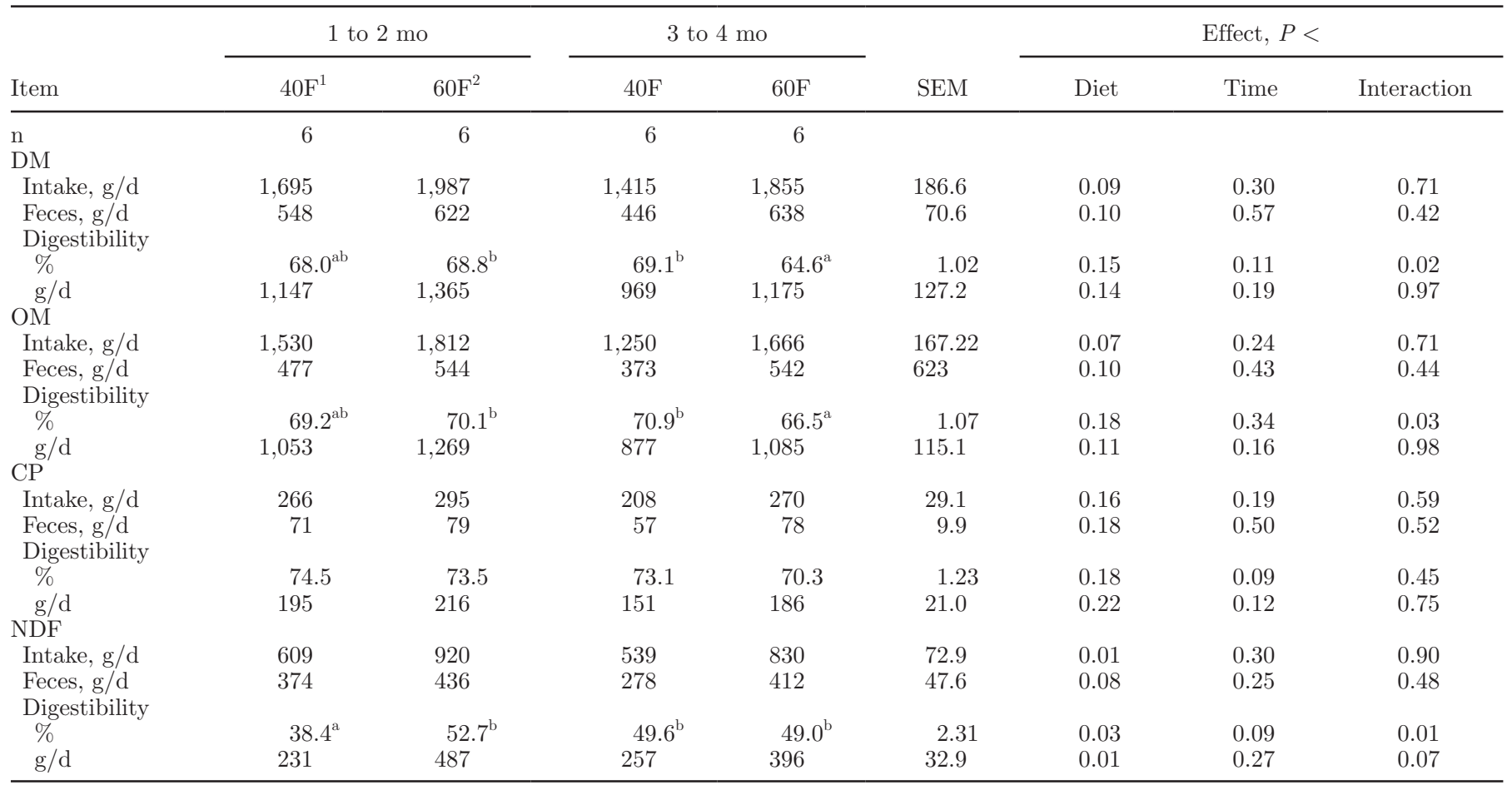

${ }^{\mathrm{a}, \mathrm{b}}$ Means within a row with different superscripts differ $(P<0.05)$.

${ }^{1} 40 \mathrm{~F}=40 \%$ forage.

${ }^{2} 60 \mathrm{~F}=60 \%$ forage.

early lactation and positive in mid- and late lactation. Dry matter intake was greater for slaughtered does than for does on the digestibility study, and was greater $(P$ $<0.05)$ for $60 \mathrm{~F}$ than for $40 \mathrm{~F}$.

Milk fat concentration was lower in mo 3 to 4 than in mo 1 to 2 and 5 to $6(P<0.05$; Table 3$)$. There were diet $\times$ time interactions $(P<0.05)$ in milk concentrations of protein, lactose, and SNF. Protein concentration either was lowest or tended to be lowest among times at 3 to 4 mo. Protein concentration for $40 \mathrm{~F}$ was highest among times for 1 to 2 mo $(P<0.05)$, but for the $60 \mathrm{~F}$ diet tended to be highest at 5 to 6 mo. There were no differences among times in lactose concentration for $40 \mathrm{~F}$, but for $60 \mathrm{~F}$ lactose concentration was greater at 1 to 2 mo compared with 3 to 4 mo $(P<0.05)$. Total solids concentration was less at 3 to 4 mo compared with the earlier and later times $(P<0.05)$. Milk yield uncorrected and corrected to $4 \%$ fat was greater at 1 to 2 and 3 to 4 mo compared with 5 to 6 mo $(P<0.05)$. Fat and protein yields were greater $(P<0.05)$ at 1 to 2 mo than at 3 to 4 and 5 to 6 mo. Conversely, yields of fat, SNF, and TS were lowest among times $(P<0.05)$ for 5 to 6 mo. Log SCC was greater in 5 to 6 mo than in 1 to 2 and 3 to 4 mo of lactation $(P<0.05)$.

\section{Slaughter Measures}

Organ and Tissue Mass. Body weight and tissue and organ mass at 0 mo are given in Table 4 . For measures at 2, 4, and 6 mo, mass of the carcass in percentage of EBW was less and that of total noncarcass components was greater for $40 \mathrm{~F}$ than for $60 \mathrm{~F}$ ( $P$ $<0.05$; Table 5 ). There were no interactions between diet and time in mass of noncarcass organs and tissues in percentage of EBW. Internal fat mass in percentage of EBW was greater for $40 \mathrm{~F}$ than for $60 \mathrm{~F}(P<0.05)$ and mass of the GIT was greater $(P<0.05)$ for $60 \mathrm{~F}$ than for 40F. Mass in percentage of EBW of many noncarcass components decreased with advancing time (i.e., blood, head, kidneys, trachea, lungs, liver, skin, esophagus, GIT). Conversely, mass of internal fat increased with advancing time, being greater at 5 to 6 mo compared with earlier times $(P<0.05)$. There were interactions between diet and time for all expressions of GIT digesta mass $(P<0.05)$. Digesta mass was similar between diets at 1 to 2 mo but was greater for $60 \mathrm{~F}$ than for $40 \mathrm{~F}$ at 3 to 4 and 5 to $6 \mathrm{mo}(P<0.05)$. For $40 \mathrm{~F}$, digesta mass declined with advancing time, whereas for $60 \mathrm{~F}$ digesta mass was greater at 3 to 4 mo than at 1 to 2 mo and tended to be greater than at 5 to 6 mo. 
Table 3. Effects of dietary concentrate level on ADG, change in BCS, and milk composition and yield by Alpine does at 1 to 2,3 to 4 , and 5 to 6 mo of lactation

\begin{tabular}{|c|c|c|c|c|c|c|c|c|c|c|c|c|}
\hline \multirow[b]{2}{*}{ Item } & \multicolumn{3}{|c|}{$40 \mathrm{~F}^{1}$} & \multicolumn{3}{|c|}{$60 \mathrm{~F}^{2}$} & \multirow[b]{2}{*}{ SEM } & \multicolumn{3}{|c|}{ Month of lactation } & \multirow[b]{2}{*}{$\mathrm{SE}$} & \multirow[b]{2}{*}{ Diet, $P<$} \\
\hline & 1 to $2 \mathrm{mo}$ & 3 to $4 \mathrm{mo}$ & 5 to $6 \mathrm{mo}$ & 1 to $2 \mathrm{mo}$ & 3 to $4 \mathrm{mo}$ & 5 to $6 \mathrm{mo}$ & & 1 to 2 & 3 to 4 & 5 to 6 & & \\
\hline $\mathrm{ADG}, \mathrm{g} / \mathrm{d}$ & -136 & 24 & 121 & -61 & 46 & 73 & 25.2 & $-99^{\mathrm{a}}$ & $35^{\mathrm{b}}$ & $97^{\mathrm{c}}$ & 17.8 & 0.42 \\
\hline $\mathrm{BCS}^{3}$ change & -0.56 & 0.55 & 0.39 & -0.14 & 0.42 & 0.33 & 0.127 & $-0.35^{\mathrm{a}}$ & $0.49^{\mathrm{b}}$ & $0.36^{\mathrm{b}}$ & 0.090 & 0.48 \\
\hline DMI, kg/d & 2.23 & 2.14 & 2.10 & 2.42 & 2.81 & 2.55 & 0.130 & & & & & 0.01 \\
\hline \multicolumn{13}{|l|}{ Milk composition } \\
\hline Fat, $\%$ & 3.84 & 2.87 & 3.26 & 2.99 & 2.40 & 3.17 & 0.188 & $3.42^{\mathrm{b}}$ & $2.63^{\mathrm{a}}$ & $3.21^{\mathrm{b}}$ & 0.133 & 0.01 \\
\hline Protein, \% & $2.84^{\mathrm{d}}$ & $2.39^{\mathrm{ab}}$ & $2.51^{\mathrm{bc}}$ & $2.59^{\mathrm{bc}}$ & $2.25^{\mathrm{a}}$ & $2.75^{\mathrm{cd}}$ & 0.088 & & & & & \\
\hline Lactose, \% & $4.23^{\mathrm{bc}}$ & $4.24^{\mathrm{bc}}$ & $4.17^{\mathrm{ab}}$ & $4.33^{\mathrm{c}}$ & $4.06^{\mathrm{a}}$ & $4.16^{\mathrm{ab}}$ & 0.050 & & & & & \\
\hline SNF, $\%$ & $7.98^{\mathrm{c}}$ & $7.52^{\mathrm{b}}$ & $7.57^{\mathrm{b}}$ & $7.79^{\mathrm{bc}}$ & $7.20^{\mathrm{a}}$ & $7.80^{\mathrm{bc}}$ & 0.103 & & & & & \\
\hline TS, \% & 11.82 & 10.39 & 10.83 & 10.77 & 9.60 & 10.96 & 0.264 & $11.30^{\mathrm{b}}$ & $9.99^{\mathrm{a}}$ & $10.90^{\mathrm{b}}$ & 0.187 & 0.02 \\
\hline $\mathrm{SCC}^{4}$ & 1.20 & 0.68 & 2.16 & 0.63 & 0.82 & 1.19 & 0.502 & & & & & \\
\hline Log SCC & 5.89 & 5.82 & 6.18 & 5.71 & 5.75 & 6.02 & 0.133 & $5.80^{\mathrm{a}}$ & $5.78^{\mathrm{a}}$ & $6.10^{\mathrm{a}}$ & 0.094 & 0.22 \\
\hline \multicolumn{13}{|l|}{ Milk yield } \\
\hline Uncorrected, $\mathrm{kg} / \mathrm{d}$ & 3.67 & 3.25 & 2.77 & 3.48 & 3.77 & 2.39 & 0.324 & $3.58^{\mathrm{b}}$ & $3.51^{\mathrm{b}}$ & $2.58^{\mathrm{a}}$ & 0.229 & 0.97 \\
\hline $4 \%$ fat-corrected, $\mathrm{kg} / \mathrm{d}$ & 3.60 & 2.78 & 2.45 & 3.02 & 3.00 & 2.14 & 0.285 & $3.31^{\mathrm{b}}$ & $2.89^{\mathrm{b}}$ & $2.30^{\mathrm{a}}$ & 0.202 & 0.35 \\
\hline Fat, g/d & 141 & 94 & 86 & 103 & 91 & 76 & 10.9 & $122^{\mathrm{b}}$ & $93^{\mathrm{a}}$ & $81^{\mathrm{a}}$ & 7.7 & 0.08 \\
\hline Protein, g/d & 104 & 77 & 67 & 90 & 85 & 66 & 7.7 & $97^{\mathrm{b}}$ & $81^{\mathrm{a}}$ & $67^{\mathrm{a}}$ & 5.5 & 0.70 \\
\hline Lactose, $\mathrm{g} / \mathrm{d}$ & 156 & 138 & 114 & 151 & 153 & 99 & 13.4 & $153^{\mathrm{b}}$ & $146^{\mathrm{b}}$ & $107^{\mathrm{a}}$ & 9.5 & 0.87 \\
\hline $\mathrm{SNF}, \mathrm{g} / \mathrm{d}$ & 293 & 244 & 206 & 271 & 271 & 186 & 23.4 & $282^{\mathrm{b}}$ & $258^{\mathrm{b}}$ & $196^{\mathrm{a}}$ & 1.7 & 0.81 \\
\hline TS, g/d & 434 & 338 & 293 & 374 & 363 & 263 & 33.4 & $404^{\mathrm{b}}$ & $350^{\mathrm{b}}$ & $278^{\mathrm{a}}$ & 23.6 & 0.44 \\
\hline
\end{tabular}

${ }^{\mathrm{a}-\mathrm{d}}$ Means within a row with different superscripts differ $(P<0.05)$.

${ }^{1} 40 \mathrm{~F}=40 \%$ forage

${ }^{2} 60 \mathrm{~F}=60 \%$ forage

${ }^{3} 1$ to 5 , with $1=$ extremely thin and $5=$ extremely obese.

${ }^{4} \times 10^{6} / \mathrm{mL}$. 
Body Composition. The mass of internal fat in does soon after birth was considerably greater than that in the carcass, with a fat concentration in noncarcass tissues about twice as great as in the carcass (Table 6). Correspondingly, there was much more protein at 0 mo in the carcass than in noncarcass tissues.

The $40 \mathrm{~F}$ diet resulted in greater fat mass during lactation in the carcass $(P<0.08)$ and noncarcass tissues $(P<0.05)$ compared with the $60 \mathrm{~F}$ diet (Table 7$)$. Mass of fat in noncarcass tissues was considerably less at 2 and 4 mo of lactation compared with that at 0 mo, although values for the carcass were not greatly different. Mass of fat was greater at 6 than at 2 and 4 mo of lactation for both the carcass and noncarcass tissues, although the magnitude of change was much greater for noncarcass tissues. At 6 mo, mass of fat in the carcass and noncarcass tissues was greater than at 0 mo. Neither diet nor month of lactation affected protein or water mass in the carcass, noncarcass tissues, or empty body. Thus, effects of diet and month of lactation on energy stores were similar to those on fat mass.

Diet did not affect ash, protein, or water concentrations in the carcass, although the concentration of fat tended $(P<0.06)$ to be greater for $40 \mathrm{~F}$ than for $60 \mathrm{~F}$ (Table 7). Conversely, diet affected levels of all constituents in noncarcass tissues $(P<0.05)$. Levels of fat and energy were greater and those of ash, protein, and water were less for $40 \mathrm{~F}$ than for $60 \mathrm{~F}$. Concentrations of fat were greater at mo 6 than at mo 2 and 4 of lactation for both the carcass and noncarcass tissues, but the magnitude of difference was much greater for noncarcass tissues.

Despite numerous effects of diet on mass and concentrations in the carcass, noncarcass tissues, and empty body at slaughter times, there were no significant $(P$ $>0.10$ ) effects on estimates of daily change in mass (Table 8). This was a result of high variability and estimation of initial values based on averages on a full BW basis of values for the same diet at the preceding time of slaughter. In accordance, concentrations in tissue being lost or gained are not presented because of some unrealistic values for individual observations that had marked effects on means.

There was much greater mobilization of noncarcass tissues than of the carcass in the first 2 mo of lactation (Table 8). Likewise, gain of tissue in mo 3 to 6 was greater for noncarcass tissues than for the carcass. Daily gain of fat and energy tended to be greater in mo 5 to 6 compared with 3 to 4 in noncarcass tissues $(P<0.10$ and 0.09 , respectively) and empty body $(P$ $<0.07$ ). Based on period means of daily change in wet tissue mass and energy, the energy concentration in
Table 4. Body weight, BCS, and mass of the carcass and noncarcass tissues and organs of Alpine does within 1 wk of parturition

\begin{tabular}{|c|c|c|}
\hline Item & Mean & SEM \\
\hline \multicolumn{3}{|l|}{$\mathrm{BW}, \mathrm{kg}$} \\
\hline Unshrunk & 55.5 & 4.42 \\
\hline Shrunk & 50.8 & 4.06 \\
\hline Empty & 45.2 & 3.59 \\
\hline $\mathrm{BCS}^{1}$ & 2.4 & 0.07 \\
\hline \multicolumn{3}{|l|}{ Mass, kg } \\
\hline Carcass & 22.99 & 1.682 \\
\hline Noncarcass & 22.15 & 1.940 \\
\hline Blood & 2.237 & 0.1662 \\
\hline Feet & 1.103 & 0.0758 \\
\hline Head & 2.690 & 0.1088 \\
\hline Kidneys & 0.163 & 0.0140 \\
\hline Trachea & 0.089 & 0.0108 \\
\hline Lungs & 0.433 & 0.0192 \\
\hline Liver & 0.895 & 0.0378 \\
\hline Heart & 0.234 & 0.0149 \\
\hline Spleen & 0.088 & 0.0058 \\
\hline Internal fat & 6.960 & 1.2296 \\
\hline Skin & 2.952 & 0.1643 \\
\hline Uterus & 1.273 & 0.1428 \\
\hline Esophagus & 0.100 & 0.0098 \\
\hline Reticulorumen & 1.118 & 0.1009 \\
\hline Omasum & 0.126 & 0.0157 \\
\hline Abomasum & 0.276 & 0.0406 \\
\hline Small intestine & 0.660 & 0.0479 \\
\hline Large intestine & 0.691 & 0.0373 \\
\hline Cecum & 0.066 & 0.0038 \\
\hline Gastrointestinal tract & 2.937 & 0.1917 \\
\hline \multicolumn{3}{|l|}{ Mass, $\%$ of empty BW } \\
\hline Carcass & 51.08 & 0.631 \\
\hline Noncarcass & 48.92 & 0.631 \\
\hline Blood & 4.98 & 0.183 \\
\hline Feet & 2.47 & 0.064 \\
\hline Head & 6.06 & 0.273 \\
\hline Kidneys & 0.36 & 0.018 \\
\hline Trachea & 0.21 & 0.035 \\
\hline Lungs & 0.97 & 0.040 \\
\hline Liver & 2.01 & 0.087 \\
\hline Heart & 0.52 & 0.020 \\
\hline Spleen & 0.20 & 0.013 \\
\hline Internal fat & 14.88 & 1.617 \\
\hline Skin & 6.61 & 0.215 \\
\hline Uterus & 2.86 & 0.290 \\
\hline Esophagus & 0.23 & 0.029 \\
\hline Reticulorumen & 2.48 & 0.091 \\
\hline Omasum & 0.28 & 0.033 \\
\hline Abomasum & 0.60 & 0.052 \\
\hline Small intestine & 1.50 & 0.121 \\
\hline Large intestine & 1.56 & 0.105 \\
\hline Cecum & 0.15 & 0.007 \\
\hline Gastrointestinal tract & 6.57 & 0.260 \\
\hline \multicolumn{3}{|c|}{ Gastrointestinal tract digesta } \\
\hline $\mathrm{kg}$ & 4.44 & 0.761 \\
\hline$\%$ of unshrunk BW & 7.92 & 1.447 \\
\hline$\%$ of shrunk BW & 8.69 & 1.610 \\
\hline$\%$ of empty BW & 9.85 & 1.873 \\
\hline
\end{tabular}

${ }^{1} 1$ to 5 , with $1=$ extremely thin and $5=$ extremely obese. 
¿ Table 5. Effects of diet on BW and mass of the carcass and noncarcass tissues and organs of Alpine does at 2, 4, and 6 mo of lactation

\begin{tabular}{|c|c|c|c|c|c|c|c|c|c|c|c|c|}
\hline \multirow[b]{2}{*}{ Item } & \multicolumn{3}{|c|}{$40 \mathrm{~F}^{1}$} & \multicolumn{3}{|c|}{$60 \mathrm{~F}^{2}$} & \multirow[b]{2}{*}{ SEM } & \multicolumn{3}{|c|}{ Month of lactation } & \multirow[b]{2}{*}{ SEM } & \multirow[b]{2}{*}{ Diet, $P<$} \\
\hline & $2 \mathrm{mo}$ & $4 \mathrm{mo}$ & $6 \mathrm{mo}$ & $2 \mathrm{mo}$ & $4 \mathrm{mo}$ & $6 \mathrm{mo}$ & & 2 & 4 & 6 & & \\
\hline \multicolumn{13}{|l|}{$\mathrm{BW}, \mathrm{kg}$} \\
\hline Unshrunk & 53.4 & 55.4 & 60.1 & 53.2 & 57.4 & 59.0 & 1.96 & $53.3^{\mathrm{a}}$ & $56.4^{\mathrm{ab}}$ & $59.5^{\mathrm{b}}$ & 1.38 & 0.92 \\
\hline Shrunk & 46.6 & 49.7 & 54.4 & 46.6 & 52.3 & 52.1 & 2.03 & $46.6^{\mathrm{a}}$ & $51.0^{\mathrm{b}}$ & $53.3^{\mathrm{b}}$ & 1.43 & 0.95 \\
\hline Empty & 39.6 & 44.0 & 48.7 & 39.4 & 43.0 & 45.1 & 2.08 & $39.5^{\mathrm{a}}$ & $43.5^{\mathrm{ab}}$ & $46.9^{\mathrm{b}}$ & 1.47 & 0.37 \\
\hline \multicolumn{13}{|l|}{ Mass, kg } \\
\hline Carcass & 20.11 & 22.91 & 24.91 & 20.74 & 22.66 & 23.54 & 1.025 & $20.43^{\mathrm{a}}$ & $22.79^{\mathrm{b}}$ & $24.23^{\mathrm{b}}$ & 0.722 & 0.70 \\
\hline Noncarcass & 19.51 & 21.04 & 23.77 & 18.69 & 20.33 & 21.59 & 1.131 & $19.10^{\mathrm{a}}$ & $20.69^{\mathrm{ab}}$ & $22.68^{\mathrm{b}}$ & 0.797 & 0.20 \\
\hline Blood & 2.275 & 2.500 & 2.385 & 2.423 & 2.456 & 2.324 & 0.0822 & & & & & 0.82 \\
\hline Feet & 1.119 & 1.113 & 1.102 & 1.074 & 1.153 & 1.196 & 0.0401 & & & & & 0.39 \\
\hline Head & 2.716 & 2.727 & 2.765 & 2.611 & 2.770 & 2.950 & 0.0871 & & & & & 0.59 \\
\hline Kidneys & $0.196^{\mathrm{b}}$ & $0.169^{\mathrm{a}}$ & $0.186^{\mathrm{ab}}$ & $0.183^{\mathrm{ab}}$ & $0.196^{\mathrm{b}}$ & $0.197^{\mathrm{b}}$ & 0.0067 & & & & & 0.12 \\
\hline Trachea & 0.107 & 0.095 & 0.092 & 0.108 & 0.078 & 0.760 & 0.0089 & $0.107^{\mathrm{b}}$ & $0.086^{\mathrm{a}}$ & $0.084^{\mathrm{a}}$ & 0.0063 & 0.17 \\
\hline Lungs & 0.444 & 0.434 & 0.410 & 0.446 & 0.437 & 0.462 & 0.0171 & & & & & 0.21 \\
\hline Liver & 1.136 & 1.061 & 1.061 & 1.092 & 1.116 & 1.160 & 0.0402 & & & & & 0.27 \\
\hline Heart & 0.247 & 0.272 & 0.252 & 0.238 & 0.244 & 0.260 & 0.0127 & & & & & 0.38 \\
\hline Spleen & 0.084 & 0.089 & 0.093 & 0.092 & 0.090 & 0.101 & 0.0074 & & & & & 0.36 \\
\hline Internal fat & 4.585 & 6.491 & 9.273 & 3.896 & 5.188 & 6.349 & 0.9448 & $4.212^{\mathrm{a}}$ & $5.839^{\mathrm{a}}$ & $7.811^{\mathrm{b}}$ & 0.6661 & 0.05 \\
\hline Skin & 2.700 & 2.607 & 2.952 & 2.747 & 2.745 & 2.740 & 0.1247 & & & & & 0.96 \\
\hline Uterus & 0.109 & 0.116 & 0.164 & 0.098 & 0.123 & 0.158 & 0.0154 & $0.104^{\mathrm{a}}$ & $0.120^{\mathrm{a}}$ & $0.161^{\mathrm{b}}$ & 0.0107 & 0.77 \\
\hline Esophagus & 0.130 & 0.118 & 0.098 & 0.140 & 0.144 & 0.113 & 0.0095 & $0.135^{\mathrm{b}}$ & $0.131^{\mathrm{b}}$ & $0.105^{\mathrm{a}}$ & 0.0067 & 0.55 \\
\hline Reticulorumen & $1.279^{\mathrm{abc}}$ & $1.254^{\mathrm{ab}}$ & $1.185^{\mathrm{a}}$ & $1.214^{\mathrm{a}}$ & $1.422^{\mathrm{c}}$ & $1.409^{\mathrm{bc}}$ & 0.0581 & & & & & 0.03 \\
\hline Omasum & 0.140 & 0.145 & 0.141 & 0.136 & 0.147 & 0.155 & 0.0094 & & & & & 0.66 \\
\hline Abomasum & 0.330 & 0.287 & 0.313 & 0.333 & 0.315 & 0.297 & 0.2260 & & & & & 0.80 \\
\hline Small intestine & 1.040 & 0.814 & 0.711 & 1.018 & 0.920 & 0.932 & 0.0554 & $1.029^{\mathrm{b}}$ & $0.867^{\mathrm{a}}$ & $0.822^{\mathrm{a}}$ & 0.0391 & 0.04 \\
\hline Large intestine & 0.803 & 0.670 & 0.523 & 0.823 & 0.709 & 0.629 & 0.0412 & $0.813^{\mathrm{c}}$ & $0.690^{\mathrm{b}}$ & $0.576^{\mathrm{a}}$ & 0.2910 & 0.10 \\
\hline Cecum & 0.071 & 0.074 & 0.068 & 0.079 & 0.081 & 0.085 & 0.0060 & & & & & 0.05 \\
\hline Gastrointestinal tract & $3.664^{\mathrm{c}}$ & $3.245^{\mathrm{ab}}$ & $2.941^{\mathrm{a}}$ & $3.602^{\mathrm{c}}$ & $3.594^{\mathrm{c}}$ & $3.507^{\mathrm{bc}}$ & 0.1062 & & & & & 0.01 \\
\hline \multicolumn{13}{|l|}{ Mass, $\%$ of empty BW } \\
\hline Carcass & 50.83 & 52.11 & 52.59 & 52.95 & 52.23 & 0.648 & & & & & & 0.04 \\
\hline Noncarcass & 49.17 & 47.89 & 48.78 & 47.41 & 47.05 & 0.648 & & & & & & 0.04 \\
\hline Blood & 5.76 & 5.74 & 4.94 & 6.21 & 5.76 & 5.19 & 0.239 & $5.99^{\mathrm{b}}$ & $5.75^{\mathrm{b}}$ & $5.06^{\mathrm{a}}$ & 0.167 & 0.24 \\
\hline Feet & 2.82 & 2.57 & 2.29 & 2.74 & 2.72 & 2.69 & 0.118 & & & & & 0.13 \\
\hline Head & 6.88 & 6.30 & 5.77 & 6.68 & 6.53 & 6.57 & 0.219 & $6.78^{\mathrm{b}}$ & $6.42^{\mathrm{ab}}$ & $6.17^{\mathrm{a}}$ & 0.155 & 0.14 \\
\hline Kidneys & 0.49 & 0.39 & 0.39 & 0.47 & 0.46 & 0.44 & 0.221 & $0.48^{\mathrm{b}}$ & $0.43^{\mathrm{a}}$ & $0.41^{\mathrm{a}}$ & 0.016 & 0.08 \\
\hline Trachea & 0.27 & 0.22 & 0.19 & 0.28 & 0.18 & 0.17 & 0.025 & $0.28^{\mathrm{b}}$ & $0.20^{\mathrm{a}}$ & $0.18^{\mathrm{a}}$ & 0.018 & 0.45 \\
\hline Lungs & 1.13 & 1.01 & 0.86 & 1.15 & 1.04 & 1.04 & 0.064 & $1.14^{\mathrm{a}}$ & $1.03^{\mathrm{ab}}$ & $0.95^{\mathrm{b}}$ & 0.046 & 0.18 \\
\hline Liver & 2.87 & 2.46 & 2.23 & 2.81 & 2.63 & 2.58 & 0.119 & $2.84^{\mathrm{b}}$ & $2.54^{\mathrm{a}}$ & $2.40^{\mathrm{a}}$ & 0.084 & 0.13 \\
\hline Heart & 0.62 & 0.64 & 0.52 & 0.61 & 0.57 & 0.58 & 0.037 & & & & & 0.83 \\
\hline Spleen & 0.21 & 0.20 & 0.19 & 0.24 & 0.21 & 0.23 & 0.016 & & & & & 0.10 \\
\hline Internal fat & 11.4 & 14.27 & 18.59 & 9.39 & 11.43 & 13.70 & 1.460 & $10.39^{\mathrm{a}}$ & $12.85^{\mathrm{a}}$ & $16.14^{\mathrm{b}}$ & 1.035 & 0.02 \\
\hline Skin & 6.86 & 5.99 & 6.06 & 7.01 & 6.40 & 6.11 & 0.181 & $6.93^{\mathrm{b}}$ & $6.20^{\mathrm{a}}$ & $6.08^{\mathrm{a}}$ & 0.127 & 0.16 \\
\hline Uterus & 0.27 & 0.27 & 0.34 & 0.25 & 0.29 & 0.35 & 0.034 & $0.26^{\mathrm{a}}$ & $0.28^{\mathrm{a}}$ & $0.34^{\mathrm{b}}$ & 0.024 & 0.97 \\
\hline Esophagus & 0.33 & 0.27 & 0.20 & 0.36 & 0.34 & 0.25 & 0.026 & $0.34^{\mathrm{b}}$ & $0.30^{\mathrm{b}}$ & $0.23^{\mathrm{a}}$ & 0.019 & 0.04 \\
\hline Reticulorumen & 3.25 & 2.93 & 2.50 & 3.09 & 3.37 & 3.37 & 0.198 & & & & & 0.07 \\
\hline Omasum & 0.35 & 0.34 & 0.30 & 0.35 & 0.35 & 0.35 & 0.027 & & & & & 0.45 \\
\hline Abomasum & 0.83 & 0.67 & 0.66 & 0.86 & 0.76 & 0.66 & 0.067 & $0.85^{\mathrm{b}}$ & $0.71^{\mathrm{a}}$ & $0.66^{\mathrm{a}}$ & 0.047 & 0.47 \\
\hline Small intestine & 2.64 & 1.90 & 1.51 & 2.63 & 2.18 & 2.11 & 0.197 & $2.63^{\mathrm{b}}$ & $2.04^{\mathrm{a}}$ & $1.81^{\mathrm{a}}$ & 0.139 & 0.09 \\
\hline Large intestine & 2.00 & 1.55 & 1.10 & 2.11 & 1.66 & 1.40 & 0.099 & $2.06^{\mathrm{c}}$ & $1.60^{\mathrm{b}}$ & $1.25^{\mathrm{a}}$ & 0.070 & 0.04 \\
\hline Cecum & 0.18 & 0.17 & 0.14 & 0.20 & 0.19 & 0.19 & 0.018 & & & & & 0.06 \\
\hline Gastrointestinal tract & 9.26 & 7.56 & 6.21 & 9.24 & 8.50 & 7.87 & 0.468 & $9.25^{\mathrm{c}}$ & $8.03^{\mathrm{b}}$ & $7.04^{\mathrm{a}}$ & 0.332 & 0.04 \\
\hline
\end{tabular}


Table 6. Tissue mass and composition of Alpine does within 1 wk of parturition

\begin{tabular}{lrc}
\hline Item & Mean & SEM \\
\hline Carcass mass & & \\
Ash, kg & 1.12 & 0.088 \\
Protein, kg & 3.96 & 0.202 \\
Water, kg & 14.81 & 1.001 \\
Fat, kg & 3.00 & 0.372 \\
Energy, MJ & 209 & 19.2 \\
Noncarcass mass & & \\
Ash, kg & 0.40 & 0.036 \\
Protein, kg & 2.32 & 0.113 \\
Water, kg & 13.00 & 0.799 \\
Fat, kg & 5.51 & 0.977 \\
Energy, MJ & 270 & 38.6 \\
Empty body mass & & \\
Ash, kg & 1.53 & 0.122 \\
Protein, kg & 6.28 & 0.251 \\
Water, kg & 27.80 & 1.781 \\
Fat, kg & 8.51 & 1.346 \\
Energy, MJ & 479 & 57.7 \\
Carcass composition & & \\
Ash, \% & 4.88 & 0.116 \\
Protein, \% & 17.42 & 0.662 \\
Water, \% & 64.54 & 0.570 \\
Fat, \% & 12.82 & 0.754 \\
Energy, MJ/kg & 9.09 & 0.284 \\
Noncarcass composition & & \\
Ash, \% \% & 1.83 & 0.111 \\
Protein, \% & 10.79 & 0.924 \\
Water, \% & 59.39 & 1.852 \\
Fat, \% & 24.01 & 2.267 \\
Energy, MJ/kg & 12.44 & 0.790 \\
Empty body composition & & \\
Ash, \% Protein, \% & 3.46 & 0.124 \\
Water, \% & 14.45 & 0.639 \\
Fat, \% & 63.33 & 1.085 \\
Energy, MJ/kg & 18.75 & 1.626 \\
& 10.71 & 0.528 \\
\hline
\end{tabular}

tissue being mobilized or accreted was 16, 20, and 32 $\mathrm{MJ} / \mathrm{kg}$ in mo 1 to 2,3 to 4 , and 5 to 6 , respectively, corresponding to $7.5,5.7$, and $11.6 \%$ protein and 37,47 , and $75 \%$ fat, respectively.

\section{DISCUSSION}

\section{Feed Intake and Digestibility}

The differences in ingredient composition between diets allowed for greater intake of the $60 \mathrm{~F}$ diet, which facilitated similar milk yield. If the difference in forage level had been achieved by a greater level of bermudagrass hay rather than dehydrated alfalfa pellets, or if diets varied more in dietary forage level, intake might not have been greater for $60 \mathrm{~F}$ than for $40 \mathrm{~F}$. In this regard, in a 16-wk early-lactation study with different dietary forage levels achieved by varying the level of coarsely ground alfalfa hay, Goetsch et al. (2000) noted DMI by Alpine goats approximately $0.21 \mathrm{~kg} / \mathrm{d}$ greater for a 40 versus $80 \%$ dietary forage. In addition, stage 


\begin{tabular}{|c|c|c|c|c|c|c|c|c|c|c|c|c|}
\hline \multirow[b]{2}{*}{ Item } & \multicolumn{3}{|c|}{$40 \mathrm{~F}^{1}$} & \multicolumn{3}{|c|}{$60 \mathrm{~F}^{1}$} & \multirow[b]{2}{*}{ SEM } & \multicolumn{3}{|c|}{ Month of lactation } & \multirow[b]{2}{*}{ SEM } & \multirow[b]{2}{*}{ Diet, $P<$} \\
\hline & $2 \mathrm{mo}$ & $4 \mathrm{mo}$ & $6 \mathrm{mo}$ & $2 \mathrm{mo}$ & $4 \mathrm{mo}$ & $6 \mathrm{mo}$ & & 2 & 4 & 6 & & \\
\hline \multicolumn{13}{|l|}{ Carcass mass } \\
\hline Ash, kg & 0.87 & 0.84 & 1.07 & 0.80 & 0.92 & 1.06 & 0.071 & & & & & 0.97 \\
\hline Protein, kg & 3.49 & 3.27 & 3.91 & 3.45 & 3.66 & 3.50 & 0.279 & & & & & 0.93 \\
\hline Water, kg & 13.81 & 14.85 & 15.54 & 13.20 & 14.40 & 14.94 & 0.755 & & & & & 0.38 \\
\hline Fat, kg & 3.05 & 3.01 & 4.27 & 2.26 & 2.58 & 3.46 & 0.447 & $2.66^{\mathrm{a}}$ & $2.79^{\mathrm{a}}$ & $3.87^{\mathrm{b}}$ & 0.316 & 0.08 \\
\hline Energy, MJ & 200 & 194 & 258 & 168 & 186 & 217 & 22.5 & $184^{\mathrm{a}}$ & $190^{\mathrm{a}}$ & $237^{\mathrm{b}}$ & 15.9 & 0.15 \\
\hline \multicolumn{13}{|l|}{ Noncarcass mass } \\
\hline Ash, kg & 0.38 & 0.37 & 0.42 & 0.38 & 0.43 & 0.40 & 0.027 & & & & & 0.59 \\
\hline Protein, kg & 2.78 & 2.72 & 3.24 & 2.77 & 3.01 & 3.40 & 0.273 & & & & & 0.53 \\
\hline Water, kg & 13.11 & 11.83 & 12.17 & 11.90 & 12.39 & 12.52 & 0.533 & & & & & 0.83 \\
\hline Fat, kg & 3.98 & 5.20 & 8.30 & 2.59 & 3.47 & 5.52 & 0.957 & $3.28^{\mathrm{a}}$ & $4.34^{\mathrm{a}}$ & $6.91^{\mathrm{b}}$ & 0.677 & 0.02 \\
\hline Energy, MJ & 220 & 267 & 401 & 166 & 206 & 295 & 41.0 & $193^{\mathrm{a}}$ & $236^{\mathrm{a}}$ & $348^{\mathrm{b}}$ & 29.0 & 0.04 \\
\hline \multicolumn{13}{|l|}{ Empty body mass } \\
\hline Ash, $\mathrm{kg}$ & 1.25 & 1.21 & 1.49 & 1.18 & 1.34 & 1.46 & 0.090 & $1.22^{\mathrm{a}}$ & $1.28^{\mathrm{a}}$ & $1.48^{\mathrm{b}}$ & 0.063 & 0.91 \\
\hline Protein, kg & 6.27 & 5.99 & 7.15 & 6.22 & 6.66 & 6.90 & 0.466 & & & & & 0.75 \\
\hline Water, kg & 26.91 & 26.68 & 27.71 & 25.10 & 26.78 & 27.46 & 1.199 & & & & & 0.52 \\
\hline Fat, kg & 7.03 & 8.21 & 12.57 & 4.85 & 6.05 & 8.98 & 1.365 & $5.94^{\mathrm{a}}$ & $7.13^{\mathrm{a}}$ & $10.78^{\mathrm{b}}$ & 0.965 & 0.03 \\
\hline Energy, MJ & 421 & 461 & 659 & 334 & 392 & 512 & 60.9 & $378^{\mathrm{a}}$ & $426^{\mathrm{a}}$ & $586^{\mathrm{b}}$ & 43.1 & 0.06 \\
\hline \multicolumn{13}{|c|}{ Carcass composition } \\
\hline Ash, $\%$ & 4.07 & 3.84 & 4.20 & 4.04 & 4.25 & 4.44 & 0.281 & & & & & 0.38 \\
\hline Protein, $\%$ & 16.29 & 14.89 & 15.24 & 17.40 & 16.84 & 14.66 & 0.979 & & & & & 0.32 \\
\hline Water, \% & 64.44 & 66.89 & 61.05 & 66.32 & 66.05 & 62.86 & 1.558 & $65.38^{\mathrm{b}}$ & $66.47^{\mathrm{b}}$ & $61.95^{\mathrm{a}}$ & 1.102 & 0.47 \\
\hline Fat, $\%$ & 13.84 & 13.11 & 16.53 & 11.21 & 11.54 & 14.38 & 1.304 & $12.53^{\mathrm{a}}$ & $12.32^{\mathrm{a}}$ & $15.45^{\mathrm{b}}$ & 0.922 & 0.06 \\
\hline Energy, MJ/kg & 9.33 & 8.71 & 10.28 & 8.51 & 8.54 & 9.37 & 0.557 & & & & & 0.18 \\
\hline \multicolumn{13}{|c|}{ Noncarcass composition } \\
\hline Ash, \% & 1.88 & 1.83 & 1.72 & 2.11 & 2.20 & 1.88 & 0.136 & & & & & 0.04 \\
\hline Protein, $\%$ & 13.91 & 13.54 & 13.11 & 15.55 & 15.66 & 15.44 & 1.207 & & & & & 0.05 \\
\hline Water, $\%$ & 63.09 & 58.93 & 50.60 & 66.55 & 64.33 & 57.96 & 2.519 & $64.82^{\mathrm{b}}$ & $61.63^{\mathrm{b}}$ & $54.28^{\mathrm{a}}$ & 1.781 & 0.02 \\
\hline Fat, $\%$ & 18.59 & 24.24 & 33.28 & 14.32 & 16.46 & 24.45 & 3.006 & $16.46^{\mathrm{a}}$ & $20.35^{\mathrm{a}}$ & $28.87^{\mathrm{b}}$ & 2.126 & 0.01 \\
\hline Energy, MJ/kg & 10.81 & 12.85 & 16.28 & 9.36 & 10.23 & 13.12 & 1.090 & $10.09^{\mathrm{a}}$ & $11.54^{\mathrm{a}}$ & $14.70^{\mathrm{b}}$ & 0.771 & 0.02 \\
\hline \multicolumn{13}{|c|}{ Empty body composition } \\
\hline Ash, \% & 3.05 & 2.92 & 3.06 & 3.16 & 3.33 & 3.29 & 0.198 & & & & & 0.14 \\
\hline Protein, \% & 15.39 & 14.45 & 14.49 & 16.76 & 16.47 & 15.33 & 0.886 & & & & & 0.06 \\
\hline Water, \% & 65.03 & 63.93 & 57.25 & 67.23 & 66.05 & 61.84 & 1.953 & $66.13^{\mathrm{b}}$ & $64.99^{\mathrm{b}}$ & $59.55^{\mathrm{a}}$ & 1.381 & 0.08 \\
\hline Fat, $\%$ & 16.54 & 18.71 & 25.21 & 12.85 & 14.14 & 19.54 & 2.045 & $14.69^{\mathrm{a}}$ & $16.42^{\mathrm{a}}$ & $22.37^{\mathrm{b}}$ & 1.446 & 0.01 \\
\hline Energy, MJ/kg & 10.05 & 10.69 & 13.25 & 8.92 & 9.36 & 11.22 & 0.770 & $9.49^{\mathrm{a}}$ & $10.03^{\mathrm{a}}$ & $12.24^{\mathrm{b}}$ & 0.544 & 0.03 \\
\hline
\end{tabular}

${ }^{\mathrm{a}, \mathrm{b}}$ Main effect means of month of lactation with different superscripts differ $(P<0.05)$.

${ }^{1} 40 \mathrm{~F}=40 \%$ forage.

${ }^{2} 60 \mathrm{~F}=60 \%$ forage. 
Table 8. Effects of diet on daily tissue loss or gain by Alpine does at 2, 4, and 6 mo of lactation

\begin{tabular}{|c|c|c|c|c|c|c|c|c|c|c|c|c|}
\hline \multirow[b]{2}{*}{ Item } & \multicolumn{3}{|c|}{$40 \mathrm{~F}^{1}$} & \multicolumn{3}{|c|}{$60 \mathrm{~F}^{1}$} & \multirow[b]{2}{*}{ SEM } & \multicolumn{3}{|c|}{ Month of lactation } & \multirow[b]{2}{*}{ SEM } & \multirow[b]{2}{*}{ Diet, $P<$} \\
\hline & 1 to $2 \mathrm{mo}$ & 3 to $4 \mathrm{mo}$ & 5 to $6 \mathrm{mo}$ & 1 to $2 \mathrm{mo}$ & 3 to $4 \mathrm{mo}$ & 5 to $6 \mathrm{mo}$ & & 1 to 2 & 3 to 4 & 5 to 6 & & \\
\hline \multicolumn{13}{|l|}{ Carcass } \\
\hline Wet tissue, $\mathrm{g} / \mathrm{d}$ & -86.9 & 48.6 & 47.6 & -61.5 & 17.3 & 20.9 & 14.63 & $-74.2^{\mathrm{a}}$ & $32.9^{\mathrm{b}}$ & $34.3^{\mathrm{b}}$ & 10.35 & 0.38 \\
\hline Ash, g/d & -7.3 & 0.8 & 3.8 & -6.0 & 1.5 & 2.2 & 1.12 & $-6.6^{\mathrm{a}}$ & $1.2^{\mathrm{b}}$ & $3.0^{\mathrm{b}}$ & 0.79 & 0.93 \\
\hline Protein, g/d & -19.2 & 1.6 & 10.5 & -10.7 & 1.0 & -3.9 & 4.71 & $-15.0^{\mathrm{a}}$ & $1.3^{\mathrm{b}}$ & $3.3^{\mathrm{b}}$ & 3.32 & 0.58 \\
\hline Fat, g/d & -5.2 & 5.2 & 23.2 & -12.7 & 4.1 & 16.1 & 6.89 & $-9.0^{\mathrm{a}}$ & $4.6^{\mathrm{a}}$ & $19.7^{\mathrm{b}}$ & 4.87 & 0.37 \\
\hline Water, $\mathrm{g} / \mathrm{d}$ & $-55.2^{\mathrm{a}}$ & $40.9^{\mathrm{c}}$ & $10.2^{\mathrm{b}}$ & $-32.1^{\mathrm{a}}$ & $10.9^{\mathrm{b}}$ & $6.4^{\mathrm{b}}$ & 9.14 & & & & & 0.64 \\
\hline Energy, MJ/d & -0.65 & 0.24 & 1.15 & -0.75 & 0.18 & 0.54 & 0.337 & $-0.70^{\mathrm{a}}$ & $0.21^{\mathrm{b}}$ & $0.85^{\mathrm{b}}$ & 0.239 & 0.37 \\
\hline \multicolumn{13}{|l|}{ Noncarcass tissues } \\
\hline Wet tissue, $\mathrm{g} / \mathrm{d}$ & -68.1 & 30.8 & 68.1 & -66.2 & 15.2 & 44.1 & 17.68 & $-67.1^{\mathrm{a}}$ & $23.0^{\mathrm{b}}$ & $56.1^{\mathrm{b}}$ & 12.50 & 0.39 \\
\hline Ash, g/d & -1.3 & 0.3 & 0.8 & -0.5 & 0.6 & -0.5 & 0.45 & $-0.9^{\mathrm{a}}$ & $0.4^{\mathrm{b}}$ & $0.2^{\mathrm{b}}$ & 0.32 & 0.89 \\
\hline Protein, g/d & 1.7 & 2.1 & 8.3 & 6.9 & 1.8 & 6.0 & 4.83 & & & & & 0.83 \\
\hline Fat, g/d & -37.2 & 29.6 & 57.0 & -49.7 & 13.9 & 39.1 & 15.38 & $-43.4^{\mathrm{a}}$ & $21.8^{\mathrm{b}}$ & $41.8^{\mathrm{b}}$ & 10.87 & 0.24 \\
\hline Water, $\mathrm{g} / \mathrm{d}$ & -31.3 & -1.1 & 2.0 & -22.9 & -1.1 & -0.6 & 8.61 & $-27.1^{\mathrm{a}}$ & $-1.1^{\mathrm{b}}$ & $0.7^{\mathrm{b}}$ & 6.09 & 0.79 \\
\hline Energy, MJ/d & -1.42 & 1.21 & 2.43 & -1.79 & 0.59 & 1.68 & 0.646 & $-1.61^{\mathrm{a}}$ & $0.90^{\mathrm{b}}$ & $2.05^{\mathrm{b}}$ & 0.456 & 0.28 \\
\hline \multicolumn{13}{|l|}{ Empty body } \\
\hline Wet tissue, g/d & -155.0 & 79.4 & 115.8 & -127.7 & 32.5 & 65.0 & 30.30 & $-141.4^{\mathrm{a}}$ & $56.0^{\mathrm{b}}$ & $90.4^{\mathrm{b}}$ & 21.43 & 0.36 \\
\hline Ash, g/d & -8.6 & 1.1 & 4.6 & -6.5 & 2.0 & 1.7 & 1.41 & $-7.5^{\mathrm{a}}$ & $1.6^{\mathrm{b}}$ & $3.2^{\mathrm{b}}$ & 1.00 & 0.98 \\
\hline Protein, g/d & -17.5 & 3.7 & 18.8 & -3.8 & 2.7 & 2.1 & 8.03 & $-10.6^{\mathrm{a}}$ & $3.2^{\mathrm{ab}}$ & $10.5^{\mathrm{b}}$ & 5.68 & 0.85 \\
\hline Fat, g/d & -42.4 & 34.8 & 80.1 & -62.4 & 18.0 & 55.3 & 21.44 & $-52.4^{\mathrm{a}}$ & $26.4^{\mathrm{b}}$ & $67.7^{\mathrm{b}}$ & 15.16 & 0.25 \\
\hline Water, g/d & -86.5 & 39.8 & 12.2 & -55.0 & 9.8 & 5.8 & 15.38 & $-70.8^{\mathrm{a}}$ & $24.8^{\mathrm{b}}$ & $9.0^{\mathrm{b}}$ & 10.9 & 0.90 \\
\hline Energy, MJ/d & -2.07 & 1.45 & 3.58 & -2.54 & 0.77 & 2.22 & 0.929 & $-2.31^{\mathrm{a}}$ & $1.11^{\mathrm{b}}$ & $2.90^{\mathrm{b}}$ & 0.657 & 0.28 \\
\hline
\end{tabular}

${ }^{a-c}$ Main effect means of month of lactation and diet $\times$ month interaction means for carcass water with different superscripts differ $(P<0.05)$

${ }^{1} 40 \mathrm{~F}=40 \%$ forage.

${ }^{2} 60 \mathrm{~F}=60 \%$ forage. 
of lactation may influence effects of dietary forage level on DMI. For example, in a 16-wk late-lactation study, Goetsch et al. (2001) fed Alpine goats diets ranging from 35 to $80 \%$ forage, with differences achieved by varying the level of coarsely ground alfalfa hay, and observed similar DMI among treatments.

With a moderate to high assumed digestibility of dehydrated alfalfa pellets (NRC, 2007), a substantial dietary difference in digestibility was not expected. It is not readily apparent why OM digestibility was slightly less for $60 \mathrm{~F}$ than for $40 \mathrm{~F}$ in mo 3 to 4 or why NDF digestibility was markedly less for $40 \mathrm{~F}$ than for $60 \mathrm{~F}$ in mo 1 to 2 .

\section{Milk Composition}

The absence of a diet effect on milk fat concentration reflects the moderate level of cereal grain in the $40 \mathrm{~F}$ diet. However, Goetsch et al. $(2000,2001)$ also reported similar milk fat concentrations in Alpine goats consuming diets varying greatly in dietary forage level (i.e., 40 to 80 and 35 to $80 \%$, respectively). The greater milk protein concentration in the present experiment for $40 \mathrm{~F}$ than for $60 \mathrm{~F}$ in mo 1 to 2 agrees with a difference noted by Goetsch et al. (2000) between 40 and $80 \%$ forage diets. Furthermore, in late lactation Goetsch et al. (2001) observed a similar protein concentration among diets 65,50 , and $35 \%$ in forage, with a slightly greater level noted for an $80 \%$ forage diet.

In accordance with the greatest log SCC among periods of measurement for mo 5 to 6 , SCC in goats generally increases with advancing stage of lactation. For example, Gomes et al. (2006) reported that SCC increased from $2.56 \times 10^{5} / \mathrm{mL}$ at 1 mo of lactation to $6.51 \times 10^{5} / \mathrm{mL}$ in mo 8. Paape et al. (2007) found that SCC in dairy goats was 2.5 to 4 times higher at 15 than at 285 DIM.

\section{Mass of the Carcass and Noncarcass Tissues and Organs}

There was a substantial increase in liver mass of does from parturition to early lactation (e.g., 2 mo) and a gradual decline thereafter. This exemplifies the influence of tissue mobilization in early lactation, in addition to dietary nutrient intake, on liver metabolic activity. Lactating Alpine does mobilize considerable internal fat in early lactation, particularly with diets moderate to high in forage (e.g., 60F). Likewise, Eknæs et al. (2006) noted a steady decrease in mass of adipose tissue of Norwegian dairy goats from d 11 to 125 of lactation (i.e., 7.35 to $3.87 \mathrm{~kg}$ ). Thus, it is quite important that internal fat mass at the time of parturition with diets moderate to high in forage be adequate to realize high milk production in early lactation, to minimize mobilization of tissue protein, or both. Eknæs et al. (2006) did not observe a decrease in mass of proteinaceous tissue of Norwegian dairy goats when adipose tissue mass was declining, although Barnes and Brown (1990) noted the importance of protein mobilization to maintain milk production by Alpine goats when nutrient intake was limiting. Results of the present experiment suggest that the diet lower in forage and higher in concentrate not only lessened internal fat loss in early lactation but promoted greater internal fat accretion than the diet higher in forage in mid- and late lactation. Hence, with does in low BCS at parturition, a relatively low forage level would be advantageous to avoid depletion of this energy store and to minimize tissue protein mobilization. Conversely, with does in moderate to high body condition at parturition, a diet higher in forage can be fed without an adverse impact on milk yield because of adequate stored energy in internal fat available for mobilization in early lactation. The time taken to replenish the internal fat energy storage depot is longer with diets higher in forage, extending into late lactation and possibly the dry period. Likewise, feeding a diet lower in forage throughout lactation may result in accretion of considerable, and perhaps excessive, internal fat in mid- to late lactation. Thus, an increase in dietary forage level in mid- to late lactation may be warranted.

Even though considerable energy is mobilized in early lactation to support milk production, there is a substantial increase in mass of the GIT in the first 2 mo of lactation, followed by a steady decline. Such a change may contribute to the observation by Eknæs et al. (2006) of no change in whole body protein mass by Norwegian dairy goats in early and midlactation when fat was being mobilized. Based on tissue mass in the present experiment, it would appear that more energy is expended by the GIT with diets higher than lower in forage. Similarly, Goetsch (1998) suggested that in sheep, the physical nature of the diet influences energy expended by the GIT, with relatively high energy use relative to absorbed energy for high-forage diets and forages of low compared with high quality.

\section{Tissue Mass and Composition}

Tissue mass and composition measures support earlier interpretations based on mass of the carcass and noncarcass tissues and organs. These findings are in general agreement with those of Ngwa et al. (2007a) in a study involving yearling meat goats. That is, the energy concentration in tissue being mobilized or accreted is not constant throughout feeding periods, as 
is assumed in most sets of goat nutrient requirement recommendations, such as those of AFRC (1998), Sahlu et al. (2004), and NRC (2007). For lactating Alpine does in the present experiment, the energy concentration in tissue being mobilized in early lactation and gained in midlactation was considerably less than that being accreted in late lactation, although such differences presumably would be influenced by prior ADG and plane of nutrition. Both diets of the present experiment, although differing in forage and concentrate levels, were of moderate to high nutritive value. Lower quality diets, perhaps resulting in greater tissue mobilization in early lactation, less tissue gain and energy accretion in midlactation, or both, could prevent or delay accretion of tissue very high in fat and energy, primarily in noncarcass tissues, in late lactation.

Another important consideration regarding tissue loss and gain during lactation by dairy goat breeds such as the Alpine is initial carcass mass and composition. Considerable protein was mobilized from the carcass in early lactation, whereas throughout lactation, protein mass in noncarcass tissues increased. A low body condition at the time of kidding would restrict this pool of nutrients available for use in support of milk production. However, because does of this experiment after kidding had an average BCS slightly less than the moderate score of 3.0, it would appear that a very low body condition would be necessary to minimize carcass tissue protein mobilization in early lactation for use in milk synthesis.

The AFRC (1998) reviewed literature available at that time pertaining to the energy concentration in tissue mobilized or gained by lactating dairy goats. Considerable variability in estimates was noted. Because some estimates were similar to the ARC (1980) value of 23.9 $\mathrm{MJ} / \mathrm{kg}$ of live weight change used for lactating cattle and sheep, this was the recommendation presented. This concentration does seem appropriate as an average over an entire lactation. Based on findings of this experiment, its use would appreciably overestimate the tissue contribution to milk synthesis in early lactation and slightly overestimate energy accretion along with a slight underestimation of the dietary energy need for tissue gain in midlactation; magnitudes of error in late lactation for energy accretion would be much greater than in midlactation. However, as pointed out by AFRC (1998), in some cases there is a nominal change in the BW of dairy goats during lactation, which would minimize the impact of assumptions of energy concentration in tissue being lost or gained.

\section{CONCLUSIONS}

Dairy goats mobilize considerable fat from noncarcass tissues and a lesser amount of carcass protein in early lactation. Diets relatively low in forage lessen internal fat mobilization in early lactation and promote greater repletion later compared with diets higher in forage. The energy concentration in tissue mobilized in early lactation and accreted in midlactation is less than in tissue gained in late lactation.

\section{ACKNOWLEDGMENTS}

This project was supported by USDA Project Number 03-38814-13923.

\section{REFERENCES}

AFRC. 1998. The Nutrition of Goats. CAB International, New York, NY.

AOAC. 1990. Official Methods of Analysis. 15th ed. Assoc. Off. Anal. Chem., Arlington, VA.

ARC. 1980. The Nutrient Requirements of Ruminant Livestock. Commonwealth Agricultural Bureaux, Slough, UK.

Barnes, D. M., and D. L. Brown. 1990. Protein reserves in lactating dairy goats. Small Rumin. Res. 3:19-24.

Eknæs, M., K. Kolstad, H. Volden, and K. Hove. 2006. Changes in body reserves and milk quality throughout lactation in dairy goats. Small Rumin. Res. 63:1-11.

Goetsch, A. L. 1998. Splanchnic tissue energy use in ruminants that consume forage ad libitum. J. Anim. Sci. 76:2737-2746.

Goetsch, A. L., G. Detweiler, T. Sahlu, R. Puchala, and L. J. Dawson. 2001. Dairy goat performance with different dietary concentrate levels in late lactation. Small Rumin. Res. 41:117-125.

Goetsch, A. L., R. Puchala, M. Lachica, T. Sahlu, and L. J. Dawson. 2000. Effects of dietary levels of forage and ruminally undegraded protein on early lactation milk yield by Alpine does and doelings. J. Appl. Anim. Res. 18:79-90.

Gomes, V., A. M. M. P. D. Libera, M. Paiva, K. M. Madureira, and W. P. Araújo. 2006. Effect of the stage of lactation on somatic cell counts in healthy goats (Caprae hircus) breed in Brazil. Small Rumin. Res. 64:30-34.

Ngwa, A. T., L. J. Dawson, R. Puchala, G. Detweiler, R. C. Merkel, I. Tovar-Luna, T. Sahlu, C. L. Ferrell, and A. L. Goetsch. 2007a. Effect of initial body condition of Boer $\times$ Spanish yearling goat wethers and level of nutrient intake on body composition. Small Rumin. Res. 73:13-26.

Ngwa, A. T., L. J. Dawson, R. Puchala, G. Detweiler, R. C. Merkel, I. Tovar-Luna, T. Sahlu, C. L. Ferrell, and A. L. Goetsch. 2007b. Urea space and body condition score to predict body composition of meat goats. Small Rumin. Res. 73:27-36.

NRC. 2007. Nutrient Requirements of Small Ruminants. Sheep, Goats, Cervids, and New World Camelids. Natl. Acad. Press, Washington, DC.

Paape, M. J., G. R. Wiggans, D. D. Bannerman, D. L. Thomas, A. H. Sanders, A. Contreras, P. Moroni, and R. H. Miller. 2007. Monitoring goat and sheep milk somatic cell counts. Small Rumin. Res. 68:114-125.

Sahlu, T., A. L. Goetsch, J. Luo, I. V. Nsahlai, J. E. Moore, M. L. Galyean, F. N. Owens, C. L. Ferrell, and Z. B. Johnson. 2004. Energy and protein requirements of goats: Developed equations, other considerations and future research to improve them. Small Rumin. Res. 53:191-220. 